\title{
PENINGKATAN AKTIFITAS DAN HASIL BELAJAR SBDP MELALUI MEDIA BEKAS BUNGKUS KOPI DI KELAS VI TUNAGRAHITA SLB BUDI KARYA TALAGO
}

\author{
Mahdalena Amir \\ SLB Budi Karya Talago, Indonesia \\ Email: mahdalena.amir17@gmail.com
}

\section{INFORMASI ARTIKEL}

Terkirim 08 Juli 2019

Revisi 29 Agustus 2019

Diterima 04 November 2019

\section{Kata kunci:}

SBDP, Media Bekas, Bungkus Kopi

\begin{abstract}
ABSTRAK
Penelitian ini bertujuan untuk meningkatkan hasil belajar SBDP melalui penggunaan media bekas bungkus kopi. Jenis penelitian yang digunakan adalah Penelitian Tindakan Kelas yang dilakukan sebanyak 2 siklus. Tiap siklus terdiri dari 2 pertemuan dimulai dengan perencanaan, Pelaksanaan tindakan, pengamatan dan refleksi. Alat Pengumpul data yang digunakan dalam penelitian ini adalah pedoman observasi, catatan lapangan dan hasil tugas siswa yang dianalisis secara kualitatif. Selama penelitian berlangsung kolaborator selalu mengamati guru dan siswa serta membuat catatan lapangan. Semua catatan yang diperoleh selama pengamatan tersebut dijadikan bahan perenungan atau diskusi untuk melakukan tindak lanjut kegiatan pada siklus berikutnya. Hasil penelitian mengungkapkan bahwa penggunaan media bekas bungkus kopi dapat meningkatkan keaktifan dan hasil belajar siswa kelas VI Tunagrahita SLB Budi Karya Talago
\end{abstract}

\section{Pendahuluan}

Keterampilan merupakan bagian dari pelajaran SBDP yang harus diberikan kepada semua peserta didik mulai dari sekolah dasar, banyaknya jam pembelajaran SBDP dalam struktur kurikulum merupakan tantangan bagi guru untuk berinovasi sehingga waktu yang ada dapat dimanfaatkan secara efektif dan efisian. Pembelajaran SBDP khususnya pada pembelajaran keterampilan hendaknya menarik minat peserta didik dan dapat menghasilkan produk yang bernilai ekonomis, sehingga siswa tertantang dan termotivasi untuk mempelajari dan menghasilkan produk.

Pembelajaran keterampilan sangat dibutuhkan peserta didik berkebutuhan khusus yang memiliki kekurangan didalam kemampuan akademik tetapi tidak memiliki hambatan motorik halus maupun motorik kasar. Keterampilan merupakan kebutuhan anak berkebutuhan khusus sebagai bekal untuk hidup bersama masyarakat.

Tantangan pokok yang dihadapi dalam pembelajaran keterampilan saat ini adalah kurangnya minat peserta didik untuk berlatih, hal ini menyebabkan hasil belajar yang diperoleh siswa kurang maksimal. Tantangan tersebut menjadi persoalan yang sangat perlu menjadi perhatian bagi guru agar hasil belajar siswa menjadi baik.

Sampah merupakan masalah apabila tidak dikelola dengan baik, sampah menimbulkan pemandangan yang tidak menyenangkan, sampah menimbulkan polusi udara yang busuk dan menggangu lingkungan, sampah yang terbuat dari plastik akan merusak kesuburan tanah, sampah dari plastik tidak bisa hancur beratus ratus tahun, menyebabkan tanah menjadi tandus. Banyaknya sampah yang berserakan khususnya sampah rumah tangga bekas bungkus kopi merupakan permasalahan yang harus segera diatasi, bagaimana mengelola sampah bekas bungkus kopi menjadi bahan keterampilan yang menghasilkan produk yang bernilai ekonomis.

Dengan adanya permasalahan kurang minatnya peserta didik untuk belajar SBDP, sedangkan waktu yang tersedia untuk belajar SBDP cukup banyak, permasalah produk yang harus dihasilkan dan bernilai ekonomis, permasalahan guru yang kurang berinovasi dalam mengajar, permasalahan sampah yang ada di lingkungan sekolah khususnya sampah terbuat dari plastik yang mengganggu lingkungan dan kesuburan tanah. Untuk mengatasi permasalahan diatas saya akan mengadakan Penelitian Tindakan Kelas tentang pembelajaran keterampilan yang dapat menghasilkan produk yang bernilai ekonomis dan bahannya berasal dari sampah rumah tangga yang terbuat dari plastik dengan judul "Peningkatan Aktifitas dan hasil belajar SBDP Melalui Media Bekas Bungkus Kopi di Kelas VI Tunagrahita SLB Budi Karya Talago"

\section{Kajian Teori}

A. Aktifitas Belajar

Proses merubah tingkah laku merupakan prinsip belajar. Ada tidaknya belajar dicerminkan dari ada tidaknya proses. Tanpa adanya proses belajar tidak mungkin terjadi sehingga dalam interaksi belajar mengajar proses merupakan bagian yang sangat penting.

Penggunaan metode yang tepat akan mempermudah dalam pelaksanaan proses belajar mengajar, Media yang menarik juga sangat mempengaruhi proses hal ini disebabkan siswa akan lebih tertarik. Dengan proses pembelajaran yang baik dimungkinkan untuk mendapatkan hasil belajar yang optimal.

B. Hasil Belajar

Menurut Suprijono (2012:5), hasil belajar adalah pola-pola perbuatan, nilai-nilai, pengertian-pengertian, sikap-sikap, apresiasi dan keterampilan. Selanjutnya Supratiknya (2012 : 5) mengemukakan bahwa hasil belajar yang menjadi objek penilaian kelas berupa kemampuan-kemampuan baru yang diperoleh siswa setelah mereka mengikuti proses belajar-mengajar tentang mata pelajaran tertentu. Dalam sistem pendidikan nasional 
rumusan tujuan pendidikan mengacu pada klasifikasi hasil belajar dari Bloom yang secara garis besar yaitu aspek kognitif, aspek afektif dan aspek psikomotor.

Hasil belajar adalah perubahan tingkah laku yang diperoleh dari proses belajar, dari tidak tau menjadi mengerti, dari tidak mampu menjadi mampu, dari tidak bisa menjadi bisa, Harapan dari hasil belajar adalah perubahan tingkah laku yang menyeluruh, koknitif, afektif dan psikomotor secara seimbang.

Jadi setiap saat dalam kehidupan manusia mengalami proses belajar. Belajar dilakukan manusia secara formal maupun informal dengan tujuan akan memperoleh hasil belajar yang berupa perubahan tingkah laku baik dalam kognitif, afektif maupun psikomotor.

C. Media Pembelajaran.

Media berasal dari bahasa latin merupakan bentuk jamak dari "Medium" yang secara harfiah berarti "Perantara" atau "Pengantar" yaitu perantara atau pengantar sumber pesan dengan penerima pesan. Beberapa ahli memberikan definisi tentang media pembelajaran. Schramm (1977) mengemukakan bahwa media pembelajaran adalah teknologi pembawa pesan yang dapat dimanfaatkan untuk keperluan pembelajaran. Sementara itu, Briggs (1977) berpendapat bahwa media pembelajaran adalah sarana fisik untuk menyampaikan isi/materi pembelajaran seperti : buku, film, video dan sebagainya. Sedangkan, National Education Associaton (1969) mengungkapkan bahwa media pembelajaran adalah sarana komunikasi dalam bentuk cetak maupun pandang-dengar, termasuk teknologi perangkat keras.

Dapatlah kita simpulkan dari beberapa pendapat para ahli tentang media pembelajaran adalah alat yang dapat digunakan untuk menyampaikan pesan dan akan berpengaruh terhadapat minat, motivasi siswa sehingga proses pembelajaran berjalan efektif dan efisien.

D. Barang Bekas

Berdasarkan Undang-Undang No. 18 Tahun 2008, sampah adalah sisa kegiatan sehari-hari manusia dan/atau proses alam yang berbentuk padat. Pengelolaan sampah dimaksudkan adalah kegiatan yang sistematis, menyeluruh, dan berkesinambungan yang meliputi pengurangan dan penanganan sampah. Berdasarkan sifat fisik dan kimianya sampah dapat digolongkan menjadi: 1) sampah ada yang mudah membusuk terdiri atas sampah organik seperti sisa sayuran, sisa daging, daun dan lain-lain; 2) sampah yang tidak mudah membusuk seperti plastik, kertas, karet, logam, sisa bahan bangunan danlain-lain; 3) sampah yang berupa debu/abu; dan 4) sampah yang berbahaya (B3) bagikesehatan, seperti sampah berasal dari industri dan rumah sakit yang mengandung zat-zatkimia dan agen penyakit yang berbahaya.

Pengelolaan sampah sangatlah penting karena bisa mengurangi bahaya sampah. Kegiatan mengumpulkan sampah yang terbuat dari plastik dan diolah kembali menjadi produk yang bernilai ekonomis adalah salah satu cara untuk mengurangi bahaya sampah.

E. Tunagrahita.

Anak berkebutuhan khusus tunagrahita adalah anak dengan karakteristik khusus bila dibandingkan dengan anak pada umumnya. Effendi dalam Usti (2013) menyatakan seseorang dikategorikan tunagrahita apabila memiliki tingkat kecerdasan yang sedemikian rendahnya atau dibawah normal, sehingga untuk melihat perkembangannya memerlukan bantuan atau layanan secara spesifik termasuk dalam pendidikannya. Ingatan dan perhatian anak tunagrahita lemah, tidak mampu memperhatikan sesuatu hal dengan serius dan lama, perhatian anak tunagrahita akan sering berpindah pada persoalan lain dalam waktu sekejap, apalagi dalam hal memperhatikan pelajaran, anak tunagrahita cepat merasa bosan.

Karena kecerdasan yang kurang menyebabkan anak selalu tertinggal dalam segala hal, akibatnya anak selalu diabaikan dalam keluarga dan masyakat sekitar, bahkan banyak yang menganggap

\section{Metode}

Penelitian ini merupakan Penelitian Tindakan Kelas dengan menggunakan pendekatan kualitatif. Esensi dari dari tindakan penelitian tindakan kelas terletak pada adanya tindakan dalam situasi yang dialami untuk memecahkan permasalahan praktis. Kegiatan yang dilakukan berupa siklus yang dimulai dari aspek perencanaan, melakukan tindakan sesuai rencana yang telah dipersiapkan. Melakukan pengamatan bersama dengan pelaksanaan pelaku tindakan dan melakukan refleksi untuk memproses data yang didapat pada saat dilakukan pengamatan.

Penelitian ini akan dilaksanakan 2 (dua ) siklus , tiap siklus menggunakan bekas bungkus kopi untuk membuat hasil karya keterampilan mulai dari proses awal sampai menghasilkan karya.keterampilan kelas VI Tunagrahita SLB Budi Karya Talago. Setiap siklus terdiri dari kegiatan , perencanaan, pelaksanaan tindakan dan refleksi terhadap tindakan

\section{Hasil Penelitian dan Pembahasan}

Hasil penelitian siklus I menunjukkan bahwa siswa masih ada kesulitan dalam menentukan motif dalam melipat maupun menganyam membentuk baling baling, sehingga membutuhkan bimbingan dan memerlukan waktu yang lama. Hasil pengamatan pada siklus I yang diperoleh belum mencapai hasil yang diinginkan sehingga dilaksanakan siklus II. Dalam pelaksanaan siklus II guru diharapkan memperhatikan kekurangan-kekurangan atau kelemahan-kelemahan yang ditemui pada siklus I, dan merubah atau memperbaikinya pada siklus berikutnya.

Hasil penelitian yang dilakukan terdapat peningkatan hasil akhir pada masing-masing siklus, begitu juga antara hasil akhir siklus I dan siklus II terdapat peningkatan. .Berdasarkan refleksi siklus kedua tersebut, perbedaan ini membuktikan bahwa pemakaian media bekas bungkus kopi dalam pembelajaran SBDP kelas VI Tunagrhita SLB Budi Karya Talago berpengaruh terhadap keaktifan belajar siswa dan hasil belajar siswa.

1. Keaktifan siswa

Keaktifan siswa dalam mengikuti pembelajaran dari siklus satu maupun siklus dua sama sama aktif melaksanakan pembelajaran, belum berhasilnya target pada siklus satu dikarenakan masih banyak kesulitan yang ditemui terutama dalam menentukan motif. Sedang pada siklus kedua tidak ditemui hambatan yang berati sehingga target dapat tercapai

\section{Hasil belajar siswa}

Peningkatan hasil belajar siswa pada siklus I dan siklus II dapat dijelaskan sebagai berikut :

Pada siklus satu pertemuan pertama siswa yang berhasil menyelesaikan tugas hanya satu orang dan pada pertemuan kedua sudah dua orang yang mampu menyelesaikan tugas menganyam bekas bungkus kopi menjdi kotak tisu. Sedangkan pada siklus dua siswa yang mampu menyelesaikan tugas pada pertemuan pertama sebanyak dua orang anak dan pada pertemuan kedua seluruh siswa dapat menyelesaikan tugas untuk menganyam bekas bugkus kopi menjadi kotak pensil.

Salah satu kompetensi yang harus dimiliki guru adalah kemampuan merancang dan menggunakan media dalam media dalam kegiatan pembelajaran. Pelajaran SBDP merupakan salah satu mata pelajaran yang harus menggunakan media pembelajaran. Keberhasilan guru dalam menyampaikan materi pelajaran tercermin dalam kemampuan dan ketrampilan mereka dalam menggunakan media pembelajaran tersebut, karena penggunaan media dalam kegiatan pembelajaran diyakini dapat membantu peningkatan daya serap siswa yang bermuara pada peningkatan kualitas belajar.

Berdasarkan uraian diatas dapat dikemukakan bahwa penggunaan media bekas bungkus kopi dalam pembelajaran melipat dan menganyam dapat meningkatkan keaktifan siswa dan hasil belajar siswa . Hal ini berarti bahwa media bekas bungkus kopi dapat menumbuhkan rasa dan sikap lebih mudah mengingat, memahami materi, senang merasa aktif dan kreatif dalam proses pembelajaran. 
Penggunaan media dalam kegiatan pembelajaran bukan lagi dipandang sebatas alat bantu mengajar, melainkan juga berfungsi sebagai sarana untuk menyalurkan informasi atau pesan kepada sipenerima pesan. Oleh karena itu dalam penggunaan media pembelajaran guru harus mampu menyeleksi media mana yang relevan dengan tujuan yang ingin dicapai, materi pembelajaran, mudah didapat dan digunakan oleh guru sesuai dengan keadaan siswa serta ketepatgunaan, sehingga peranan media benar-benar dapat berfungsi sebagaimana mestinya. Disamping itu penggunaan media bukan berarti mempermudah guru dalam menyampaikan materi pelajaran, tetapi justru memudahkan siswa dalam menyerap dan menguasai pelajaran sehingga dapat meningkatkan kualitas belajar siswa.

\section{Kesimpulan}

Berdasarkan pencapaian hasil kegiatan penelitian kelas maka dapat disimpulkan, sebagai berikut :

1. Inovasi pemanfaatan bekas bungkus minuman kopi dapat meningkatkan keaktifan peserta didik dalam pembelajaran melipat.

2. Inovasi pemanfaatan bekas bungkus minuman kopi dapat menghasilkan karya keterampilan.

Daftar Rujukan

Al Irsyadi, Fatah Yasin; Nugroho, Yusuf Sulistyo. Game edukasi pengenalan anggota tubuh dan pengenalan angka untuk anak berkebutuhan khusus (ABK) tunagrahita berbasis kinect. Prosiding SNATIF, 2015, 13-20.

Marliani, Novi. Pemanfaatan Limbah Rumah Tangga (Sampah Anorganik) Sebagai Bentuk Implementasi Dari Pendidikan Lingkungan Hidup. Formatif: Jurnal Ilmiah Pendidikan MIPA, 2015, 4.2.

Rochyadi, Endang. Karakteristik dan Pendidikan Anak Tunagrahita. Modul pada Universitas Pendidikan Indonesia: tidak diterbitkan, 2012.

Sudrajat, Akhmad. Media pembelajaran. On Line at http://akhmadsudrajat. wordpress. com [diunduh tanggal 9 April 2010], 2008.

Widayanti, Lusi, et al. Peningkatan Aktivitas Belajar dan Hasil Belajar Siswa dengan Metode Problem Based Learning pada Siswa Kelas VIIA MTs Negeri Donomulyo Kulon Progo Tahun Pelajaran 2012/2013. Jurnal Fisika Indonesia, 2014, 17.49. 